\title{
Development of Portable AIDS Diagnosis Device
}

\author{
Birendra Kumar Singh ${ }^{1}$, Gun-Sik Tae ${ }^{2}$, Yeon-Moon Sung ${ }^{1, \dagger}$ \\ ${ }^{1}$ Glory Bio Technologies Corp. \#1304, 220, Youngshin-ro, Youngdeungpo-gu, Seoul 07228, Republic of Korea \\ ${ }^{2}$ Department of Biological Science, College of Science \& Technology, Dankook University, 119, Dandae-ro, \\ Dongnam-gu, Cheonan-si, Chungcheongnam-do 31116, Republic of Korea
}

\section{휴대용 AIDS 검사기기 개발}

Singh Birendra Kumar ${ }^{1}$, 태건식 ${ }^{2}$, 성연문 ${ }^{1, \dagger}$

1글로리바이오텍, 대한민국 07228 서울특별시 영등포구 영신로 $220 \mathrm{KnK}$ 디지털타워 1304 호

${ }^{2}$ 단국대학교 과학기술대학 생명과학부, 대한민국 31116 충청남도 천안시 동남구 단대로 119

\begin{abstract}
AIDS 환자는 전 세계에 4,000만 명인 것으로 추산되며, 주로 개발도상국에서 대부분의 환자가 발생하고 있다. AIDS 의 원인 바이러스인 HIV는 혈중의 CD4+ T 세포에 감염되어 수개월 내지 10년 간의 잠복기간을 거치면서 $\mathrm{CD} 4+\mathrm{T}$ 세 포를 점점 파괴하여 환자의 면역기능을 저하시킨다. 이렇게 면역력이 약화된 AIDS 환자는 다양한 병증에 의해 사망 에 이르게 된다. 현재의 $\mathrm{CD} 4+\mathrm{T}$ 세포 수를 계측하는 방법은 통상 유세포분석(flow cytometry) 방법에 의해 시행되고 있다. 유세포분석 방법은 정확도가 높다는 장점이 있으나 숙련된 전문 인력이 필요하고 장비가 고가이기때문에 개발 도상국에서는 이용하기 어렵다. 본 연구결과로 마이크로 여과기를 통해 소량인 $5 \mu l$ 혈액으로부터 백혈구를 포획하고 포획된 세포에서 $\mathrm{CD} 4+\mathrm{T}$ 세포 및 $\mathrm{CD} 8+\mathrm{T}$ 세포를 분석하여 $\mathrm{AIDS}$ 를 검사하는 장비를 개발하였다. 현재의 검사 장비 보다 저렴하고 고도의 기술이 필요하지 않으며 휴대가 간편한 획기적인 AIDS 검사 장비임을 시사한다.
\end{abstract}

It is estimated that there are 40 million people with AIDS worldwide, with most cases occurring mainly in developing countries. HIV, the virus that causes AIDS, is infected with CD4 $+\mathrm{T}$ cells in the blood and gradually destroys CD4+ T cells for several months to 10 years, thereby lowering the patient's immune function. AIDS patients who have weakened immunity in this way will die from various diseases. The current method for counting the number of CD4+ T cells is usually performed by flow cytometry. The flow cytometry method has the advantage of high accuracy, but it is difficult to use in developing countries because it requires skilled professionals and equipment is expensive. As a result of this study, a device for AIDS screening was developed by capturing leukocytes from a small amount of $5 \mu l$ blood through a microfilter and analyzing CD4+ T cells and CD8+ T cells from the captured cells. cheaper and easier to carry and use than current test equipment.

KEYWORDS: IVD, POCT, Flow cytometry, AIDS, CD4, CD8

\section{Introduction}

AIDS 환자는 전 세계에 3,700 만 명인 것으로 추산되며, 주로 개발도상국에서 대부분의 환자가 발생하고 있다(Geneva,

\footnotetext{
${ }^{\dagger}$ To whom correspondence should be addressed.

E-mail: sungym00@glorybt.com

Received: 5 October 2021, Revised: 5 November 2021,

Accepted: 5 November 2021
}

2016). AIDS의 원인 바이러스인 HIV는 백혈구 중 CD4+ T 세포를 감염시켜 수개월 내지 10 년 간의 잠복기간을 거치 며 CD4+ T 세포를 200 세포/ $\mu \ell$ 미만으로 떨어뜨려 환자의 면역기능을 저하시킨다(Phillips, 2001; Phillips, 2003; Antinori, 2011). 면역력이 약화된 환자는 다양한 병증에 의해 사망에 이르게 된다.

$\mathrm{AIDS}$ 치료가 필요한지 여부를 판정하기 위해 혈중 CD4+ $\mathrm{T}$ 세포를 계측하는 방법이 있다(de Wolf, 1988; Andrew, 
2006). 이와 같은 계측 방법에는 CD4+ T 세포의 절대수를 카운트하는 방법과, 전체 림프구 수 중에 $\mathrm{CD} 4+\mathrm{T}$ 세포 수 가 차지하는 비율을 산출하는 방법(CD4/림프구), $\mathrm{CD} 8+\mathrm{T}$ 세포 수에 대한 $\mathrm{CD} 4+\mathrm{T}$ 세포 수의 비율을 산출하는 방법 (CD4/CD8)이 있다(Sauter, 2016). CD4/림프구와 CD4/CD8 는 나이에 상관없이 그 값의 변동이 비교적 적기때문에 $\mathrm{CD} 4$ 림프구와 $\mathrm{CD} 4 / \mathrm{CD} 8$ 비율을 산출하는 방법이 주로 사 용되고 있다(Sauter, 2016). WHO 가이드라인에서는 CD4+ $\mathrm{T}$ 세포수가 350 세포/ $\mu$ 이하이거나, 5 세 미만의 유아의 경 우 $\mathrm{CD} 4 /$ 림프구가 0.25 이하인 경우, $\mathrm{CD} 4 / \mathrm{CD} 8$ 이 1 미만인 경우 AIDS 치료를 개시하는 시점으로 보고 있다(Geneva, 2016).

현재, CD4+ T 세포 수를 계측하는 방법은 통상 유세포분 석(flow cytometry) 방법에 의해 시행되고 있다(de Wolf, 1988) (Figure 1). 이 검사법은 정확도가 높다는 장점이 있으나 고 가의 장비로 숙련된 전문 인럭 등 충분한 인프라가 구축된 선진국 위주로 사용되고 개발도상국에서는 이용하기 어려 우며, 몇 가지 단점들이 있다: 1) 다소 많은 $100 \mu l$ 의 혈액 이 필요하다. 2) 전문 인력의 숙련도에 따라 다르지만 다소 많은 시간(20분 이상)이 필요하다. 3 ) 고가의 장비(75,000 $\sim 100,000 \mathrm{USD}$ )로 인하여 검사비가 고가이다. 4) 검사 결과 값을 $\mathrm{CD} 4$ 수치와 CD4 비율(CD4/림프구)만 제공한다.

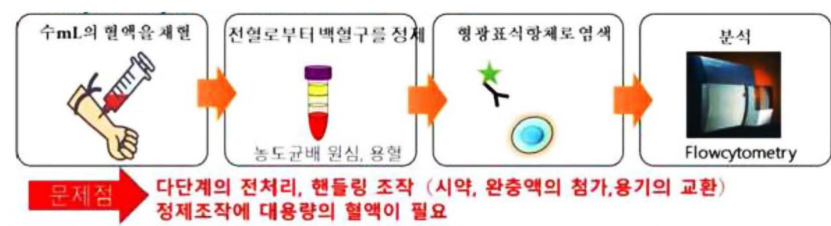

Figure 1. 유세포분석시(flow cytometry) 방법에 의한 백혈구 분 석의 흐름도

아직까지도 기존 유세포분석 검사법이 $\mathrm{CD}$ 검사 시장에 서 $70 \%$ 의 점유율을 차지하고 있다. 현재 4 개 회사에서 휴 대용 CD4 검사장비가 나와 있지만 시장에 나와 있는 $\mathrm{POC}$ (Point of Care) CD4 장비는 대부분 기존 Cytometry 방법을 이용하고 있으며, 혈액이 $10 \mu \ell$ 이상 필요하고 검사에 소요 되는 시간이 20 분 이상이며 1 일 20건의 검사밖에는 수행 할 수 없는 문제점을 가지고 있다.

게다가, 기존 $\mathrm{CD} 4$ 검사 장비들이 제공하는 검사결과는 $\mathrm{CD} 4$ 수치와 CD4 비율만 제공하고 있는데 이는 WHO 가이 드라인을 충족시키지 못하는 결과이다.

따라서 본 연구팀에서 $\mathrm{HIV}$ 환자 3,700 만명 중 $80 \%$ 가 분 포되어 있는 저소득 국가를 위한 $\mathrm{WHO}$ 가이드라인에 부합 하는 지름 $3 \mu \mathrm{m}$ 의 여과기를 통해 $5 \mu \mathrm{l}$ 의 소량의 혈액을 이
용하여 $95 \%$ 의 백혈구를 선별하여 10 분 이내에 검사할 수 있는 체외진단용 휴대용 검사장비를 제시하고자 한다.

\section{Materials and Methods}

\section{1. $\mathrm{WHO}$ 가이드라인에 적합한 휴대용 CD4 검사 솔루션}

본 개발된 시스템은 가장 적은 용량인 혈액 $5 \mu$ 를 핵심 기술인 $3 \mu \mathrm{m}$ 의 마이크로 여과기를 활용하여 $95 \%$ 의 백혈구 를 선별할 수 있어 10 분 이내에 CD4 검사가 가능하다(Figure 2).

$\mathrm{WHO}$ 가이드라인에서 요구하는 CD4 수치, CD4 비율 및 $\mathrm{CD} 4 / \mathrm{CD} 8$ 비율까지도 시 스템화하여 검사결과를 제공할 수 있다. 또한 국내 우수한 IT 기술을 융합하여 검사 결과를 중 앙 관리 기관에 저장하여 관리할 수 있도록 하여 $\mathrm{WHO}$ 에 서 $\mathrm{HIV}$ 감염 관리 및 기초 조사 연구에 big data로서 활용 할 수 있도록 개발 중이다.

본 개발 중인 시스템은 기존 해외 업체들과의 경쟁력에 서 차별화 할 수 있는 장점들을 보유하고 있기 때문에 빠 른 시장 점유를 위해서라도 시급한 개발 지원이 필요한 상 황이다.

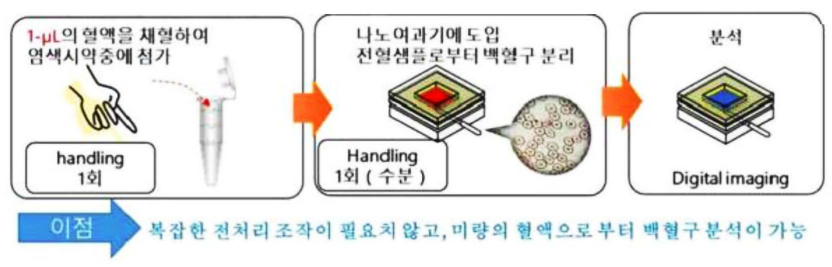

Figure 2. 본 시스템에 의한 백혈구 분석의 흐름도

\section{재료 및 방법}

$\mathrm{FITC}$ 가 결합된 $\mathrm{CD} 4$ 및 $\mathrm{PE}$ 가 결합된 $\mathrm{CD} 8$ 항체들은 Southern Biotech사(미국)에서 구입하여 사용하였다. Dimethyl sulfoxide (DMSO), 0.5\% trypsin-ethylenediaminetetraacetic acid (EDTA) solution (10×) 및 phosphate buffered saline (PBS, $\mathrm{pH}$ 7.4) 시약들은 Sigma사(미국)로부터 구입하였다. 고정액 및 유세포 분석 시약은 Beckman Coulter사(미국)에서 구입 하였다.

혈액 샘플 $5 \mu l$ 을 $\mathrm{CD}$ 항원을 표적으로 하는 형광 표지 된 항체를 포함하는 세포 염색 용액과 혼합하였다. 혈액 샘 플을 $\mathrm{RBC}$ 용해 용액과 혼합하고 실온에서 1 분 동안 반응 시킨 후 중화 용액을 첨가하였다. 그런 다음, 최종 부피가 $1 \mathrm{ml}$ 이 되도록 맞추고 20 분 동안 반응하였다. GBTsol ICA 에 샘플 주입 후 프로그램 분석을 시작하여 결과를 얻었다. 


\section{Results and Discussion}

\section{1. 마이크로 여과기(micro filter) 특성(Figure 3-5)}

마이크로 여과기는 니켈 제질로 필터의 크기는 $144 \mathrm{~mm}$, 구멍의 수는 100,000 개로 구멍 크기 및 간격은 각각 2.0 5.0 $\mu \mathrm{m}$ 와 20 25 $\mu \mathrm{m}$ 이다(Figure 3 5).

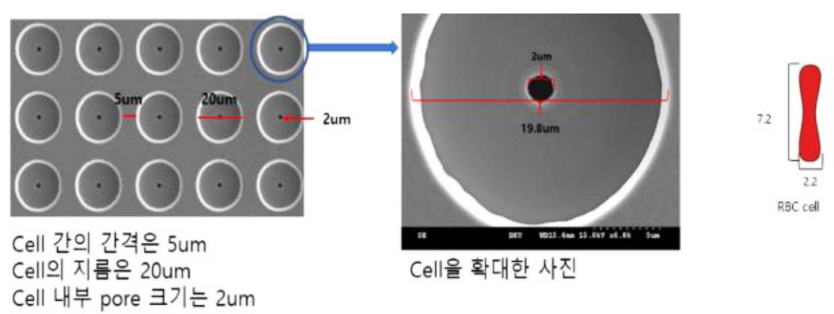

Figure 3. 전자현미경 이미지. 해상도 $5 \mu \mathrm{m}$

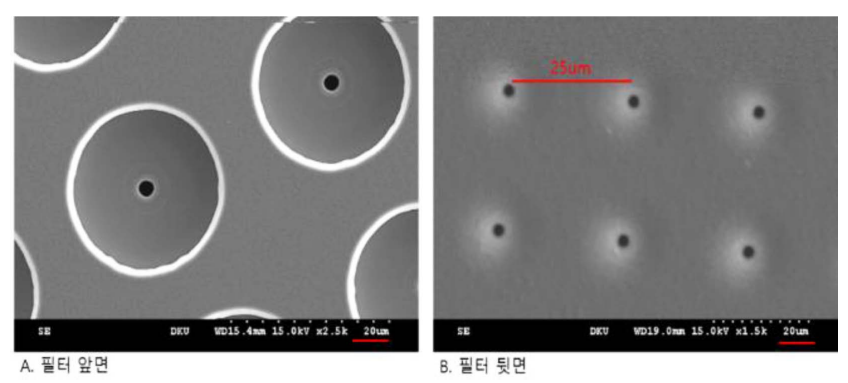

Figure 4. 여과기 구멍 간의 거리 측정한 전자현미경 이미지. 해 상도 $20 \mu \mathrm{m}$

A
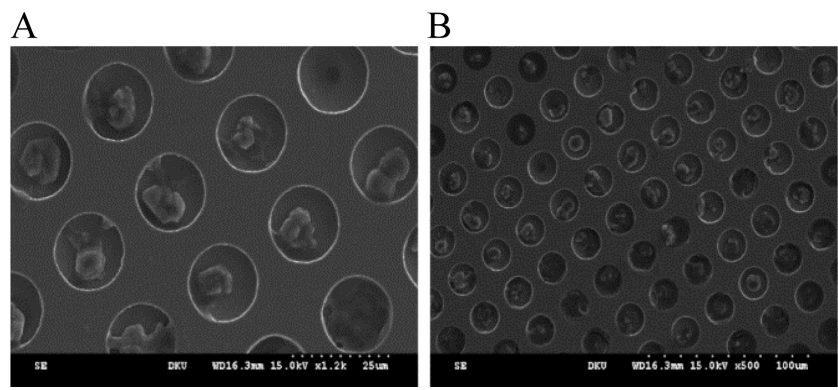

Figure 5. 각 구멍에 백혈구 포집 확인한 전자현미경 이미지. 해 상도 $25 \mu \mathrm{m}(\mathrm{A})$ 와 $100 \mu \mathrm{m}$ (B)

본 연구결과로 니켈 재질의 마이크로 여과기가 장비 개 발에 적합하다고 판단하였으나, 실제 최종 양산 단계에서는 몇 가지 해결해야 할 사항들이 있었다. 첫번째로 니켈 마이 크로 여과기의 단가가 높은 편이며, 두번째로 금속인 니켈 재질로 인하여 광원에 대한 마이크로 여과기의 빛 반사에 따른 형광 분석에 좋지 않은 영향을 줄 수 있다고 판단되 었다.
따라서, 추가적인 연구를 통해서 지금의 양산 제품에는 금 속인 니켈 재질의 마이크로 여과기에 대한 단점이 보완된 polyester(PET) 재질의 마이크로 여과기를 활용하고 있다.

\section{2. 마이크로 여과기가 부착될 카트리지 연구}

흡입부와 연결 및 분석 완료 후 기기로부터 제거가 용이 하도록 설계하였다(Figure 6). 또한 진공, 압력 등에 의한 휘 어지고 누수되는 문제점이 발생하지 않도록 설계되었다.

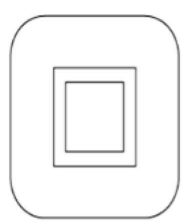

A. $2 \mathrm{D}$ 도면) 윗면)

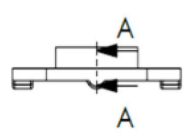

C. $2 \mathrm{D}$ 설계 도면

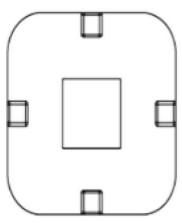

D. 2D 도면(뒷면)

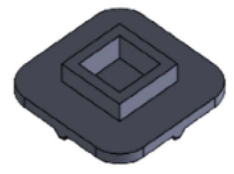

B. 3D 도면
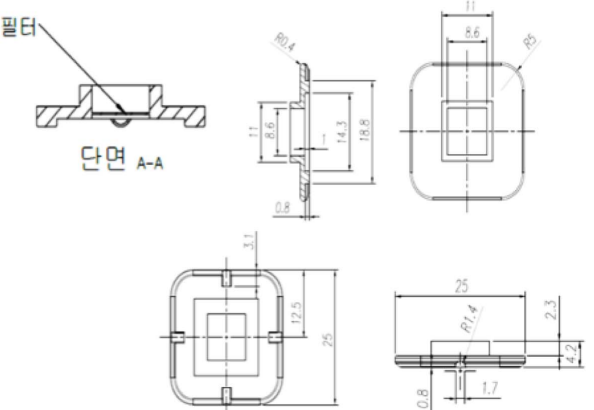

Figure 6. 카트리지 설게 도면

\section{3. 혈액 샘플 채취를 위한 전용 챔버 연구}

혈액 샘플을 채취하기 위한 전용 챔버는 정확한 용량의 $5 \mu l$ 를 채취할 수 있도록 설계하였다(Figure 7, 8). 또한 검 사 시약을 사용하여 반응 및 분주 할 수 있도록 설계되었다.

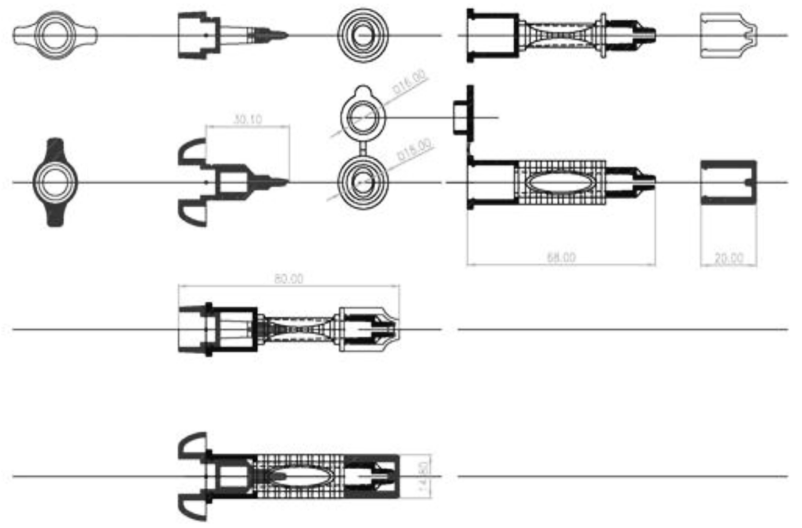

Figure 7. 혈액 샘플 채취용 챔버 설계 도면 


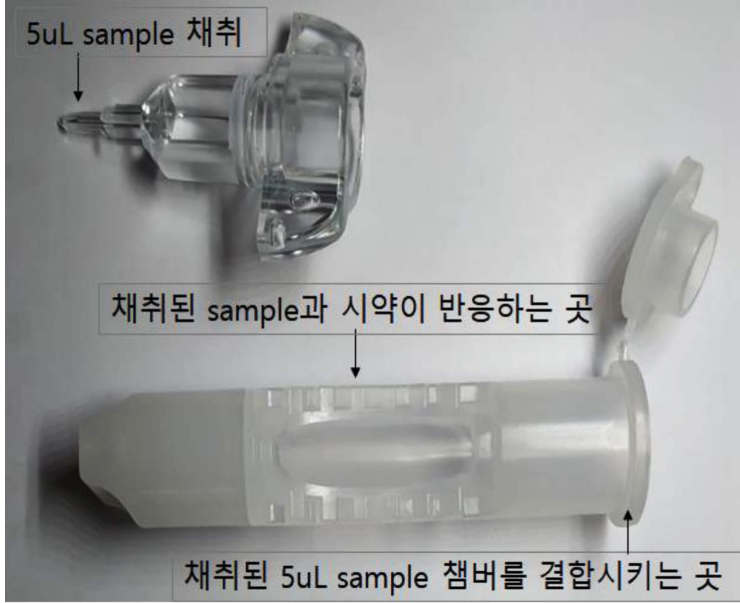

Figure 8. 샘플 채취용 챔버 시제품

\section{4. $\mathrm{CMOS}$ 기반의 광학 장비 연구}

광학 장비는 3 가지 형광을 분석하는데 적합하도록 설계 하였다(Table 1).

Table 1. CMOS 카메라 세부 사항 비교

\begin{tabular}{|c|c|}
\hline & acA4600 \\
\hline Sensor Vendor & ON Semiconductor \\
\hline Sensor & MT9F002 \\
\hline Shutter & Rolling Shutter \\
\hline Max. Image Circle & $1 / 2.3 "$ \\
\hline Sensor Type & CMOS \\
\hline Sensor Size & $6.5 \mathrm{~mm} \times 4.6 \mathrm{~mm}$ \\
\hline Resolution $(\mathrm{H} \times \mathrm{V})$ & $4608 \mathrm{px} \times 3288 \mathrm{px}$ \\
\hline Resolution & $14 \mathrm{MP}$ \\
\hline Pixel Size $(\mathrm{H} \times \mathrm{V})$ & $1.4 \mu \mathrm{m} \times 1.4 \mu \mathrm{m}$ \\
\hline Frame Rate & $10 \mathrm{fps}$ \\
\hline Mono/Color & Color \\
\hline
\end{tabular}

\section{5. 백혈구 분리 기술을 이용한 $\mathrm{CD} 4, \mathrm{CD} 8$ 검사 면역형광측 정기 연구(GBTsol ICA)}

GBTsol ICA 분석 소프트웨어는 CMOS 카메라를 통해 촬 영된 이미지를 이용하여 RGB 값을 획득하고 이 값을 3 차 원 그래프로 표시하여 개발자가 정도 관리를 할 수 있게 제 작하였다(Figure 9). 또한, 이 3차원 그래프 값을 이용하여 세포의 개수를 GBTsol ICA에 직접 숫자로 표시하거나 정 도 관리 프로그램에서 이미지 파일과 세포의 숫자로 표시 할 수 있게 개발하였다(Figure 10). 개발된 장비에 의해 CD4 및 $\mathrm{CD} 8$ 분석 가능함을 확인하였다.

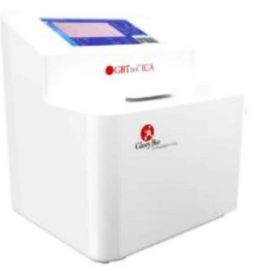

A. 외부

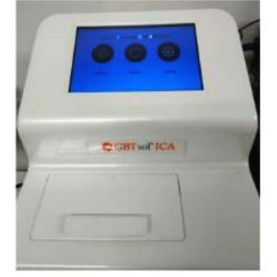

B. 상단부

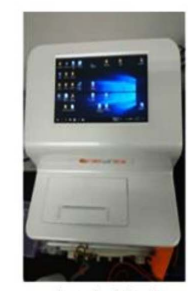

C. 초기화면

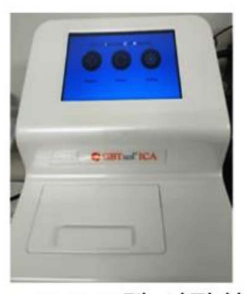

D. 프로그램 시작화면

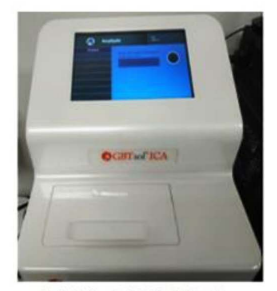

E. 분석 시작화면
Figure 9. GBTsol ICA 시제품 및 시제품의 분석소프트웨어 구현 이미지

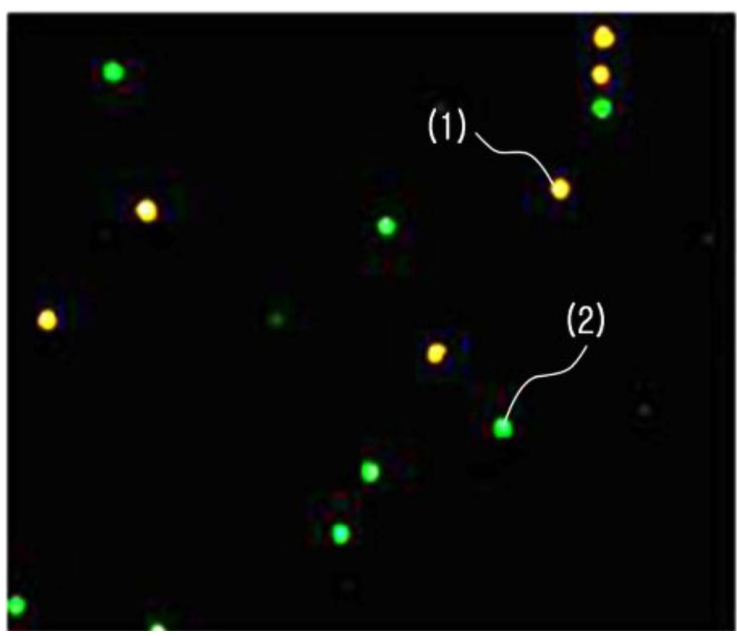

Figure 10. GBTsol ICA을 이용한 $\mathrm{CD} 4+\mathrm{T}$ 세포((2), 녹색)와 $\mathrm{CD} 8+\mathrm{T}$ 세포((1), 노란색) 분석 이미지

\section{6. 성과 및 특허}

소량의 혈액으로 백혈구를 분리하는 마이크로 여과기를 이용하여 AIDS 치료 개시의 판정 및 AIDS 치료 과정의 효 과적인 모니터링이 가능한 분석 기기 연구하는 과정에서 개 발된 혈액의 백혈구 중 CD4(세포표면항원무리 4) 및 CD8( 세포표면항원무리 8)가 발현된 세포를 직접 면역형광법을 이용해 염색한 후 그 수를 측정(계수)하여 혈액질환 진단 보 조에 도움을 주는 체외진단용 시약을 수출허가 획득하였다 (제19-4927호, 제19-4926호). 게다가 GBTsol ICA 장비는 CE 인증을 획득하였으며, 아프리카, 북미 등 여러 국가와 수출 논의 중에 있다(DE/CA29/108131/D028).

본 연구로 취득한 특허는 현재까지 총 4건이 출원 및 등 
록하였으며, 검사 장치 및 진단 방법으로 세분화되었다 (2021년 9월 기준).

\section{Conclusions}

개발된 본 면역형광측정기는 혈액 내 백혈구의 표면에 있 는 $\mathrm{CD} 4, \mathrm{CD} 8$ 등이 발현된 면역 세포의 숫자를 정밀하게 계 측하는 기능을 가지고 있다.

즉, 특정 세포들의 수치로 질병을 진단하는데 이용될 수 있다. 아울러 전처리 단계가 단순하며 검사 소요시간이 약 20 분 내로 짧으며 휴대에 용이한 크기로 개발되어 휴대가 간편하여 어느 곳에서나 검사가 가능하다. 충전 방식 전원 을 채택하여 전기가 공급되지 않은 곳에서도 사용 가능하 다는 장점이 있다.

본 연구로 개발된 GBTsol ICA는 기존 유세포분석기와 비 교하여 분석결과 이미지가 외장 USB 메모리 칩에 저장되 며 4개 이상의 형광을 분석할 수 없다는 단점이 있다. 그럼 에도 불구하고, 마이크로 여과기를 통해 혈액으로부터 백혈 구를 포획하고 포획된 세포에서 $\mathrm{CD} 4+\mathrm{T}$ 세포, $\mathrm{CD} 8+\mathrm{T}$ 세 포 등을 분석하여 AIDS 치료 개시 시기 및 AIDS 치료 과 정을 효과적으로 모니터링이 가능한 기존 장비보다 향상된 정확도, 저렴한 가격, 단순한 전처리 단계, 고도의 기술 필 요없이 간편하게 사용할 수 있는 편리성 및 작은 크기로 이 동과 휴대가 쉬운 장점이 있다.

우리는 본 연구 통해 소량의 혈액을 이용하여 효과적으 로 간편하고 편리하게 $\mathrm{AIDS}$ 를 검사할 수 있는 장비를 개 발하였다. 더불어, 면역 세포 치료를 받은 환자의 면역 세 포 모니터링, 조혈모세포 이식 후 면역계의 모니터링 등 면 역 세포를 이용한 다양한 모니터링 및 진단 검사 등에 적
용이 가능할 것임을 시사한다.

\section{Acknowledgements}

본 연구는 2017년 중소기업청 산학연 산학협력연구개발 사업단의 지원을 받았습니다(과제번호 S2501680).

\section{References}

Antinori, A. (2011) Late presentation of HIV infection: a consensus definition, HIV Medicine, 12(1), pp. 61-64.

de Wolf. (1988) Numbers of CD4+ cells and the levels of core antigens of and antibodies to the human immunodeficiency virus as predictors of AIDS among seropositive homosexual men, The Journal of Infectious Diseases, 158(3), pp. 615-622.

Geneva. (2016) World Health Organization. Consolidated Guidelines on the Use of Antiretroviral Drugs for Treating and Preventing HIV Infection: Recommendations for a Public Health Approach.

Phillips, A. N. (2001) HIV viral load response to antiretroviral therapy according to the baseline CD4 cell count and viral load. JAMA. 286(20), pp. 2560-2567.

Phillips, A. N. (2003) When should antiretroviral therapy be started for HIV infection? Interpreting the evidence from observational studies, AIDS, 17(13), pp. 1863-1869.

Phillips, A. N. (2006) The CD4 lymphocyte count and risk of clinical progression, Current Opinion in HIV and AIDS, 1(1), pp. 43-49.

Sauter, R. (2016) CD4/CD8 ratio and CD8 counts predict CD4 response in HIV-1-infected drug naive and in patients on cART, Medicine, 95(42), e5094. 